\title{
A BAT AT SINTALUTA
}

\author{
MRS. E. L. WILLOUGHBY
}

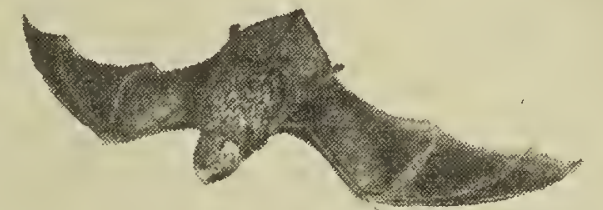

The other day we saw a bat hanging on a small tree in the garden. This bat was a rich chestnut color. It is the first bat I have seen for about twenty years, but the two I saw previous to this were of a rather mouse color.

Are there two colors of bats? Are there different kinds or do they just differ in color?

Editor's Note: Bats are more numerous in Saskatchewan than most of us realize. Their nocturnal habits tend to make them very inconspicuous. Yes, there are several species of bats in Saskatchewan, their wing color varies from a reddish hue to a light tan and their body fur from a grey through various shades of brown to almost black.

Four species have been found at Regina. The largest is the Hoary Bat, with reddish wings, perhaps ten inches from tip to tip. The fur is brown interspersed with white hairs -hence the name "Hoary". The Eastern Red Bat is a little smaller. Both its body and wings are of a reddish tinge. The Pale Big Brown Bat has a grey body and the tan or light brown wings are almost transparent. The smallest we have here is the Silver-haired Bat. The fur on the body of this little mammal is nearly black.

I am not sure which you saw at Sintaluta, but I suspect it was the Eastern Red Bat.

\section{"BUT FORGET NOT THE TREES AND THE GARDENS"}

ISABELLE POWELL

Lancer and Swift Current

There is nothing that gives more pleasure than driving along the prairie highways and passing farm buildings beautified by trees and flowers, but we pass so many yards as bare as when they were first homesteaded!

Although it takes long hours of hoeing and cultivating the young trees, the reward comes when returning home to the oasis of poplar, elm, evergreen and maple. My husband often remarks on viewing the results of his labor: "Why was it not compulsory to plant a certain number of trees as well as the regulation shack and breaking, when homesteading the land." Would this have been the answer to so much water erosion, soil drifting and drought? It may have helped in the discouraging cycle of dry years following the wet years. As Robert Moon said in "This is Saskatchewan," "The land has been our friend and our tormentor and none knew the right thing to do then, only the third di- mensional element, time, can bring things back to some order."

\section{A HARDY EASTER LILY}

MRS. A. GERVAS HOLMES, Keewatin, Ont.

I had an experience this year with an Easter lily that I thought might be of interest to readers of "The Blue Jay."

On Easter Sunday, 1952, I was the recipient of a beautiful Easter Lily, and after the blooms died, I planted the bulb in our garden at our camp on the Winnipeg River; and forgot all about it.

This summer in late July I noticed a long white bud among other flowers in the garden; and I then remembered having planted the Easter Lily bulb the previous spring. On close examination I found it had sent out two shoots with three large buds, which opened out about a week later, into three of the most beautiful lilies.

Last winter was quite severe and the bulb had no protection whatever; but this fall I will cover it with leaves and hope that it may bloom again next year. 